\title{
25 Research Suare \\ Geographic information system based malaria risk analysis and mapping in Erer District eastern Ethiopia
}

\section{Maereg Teklay A Amare}

haramaya university

Gebrehiwot Gebretsadik kassa ( $\sim$ gebrishbiochem@gmail.com )

aksum university, axum, Ethiopia. https://orcid.org/0000-0001-6848-1048

\section{Esie G/wahid Gebre}

Harkivs'kij nacional'nij universitet imeni V N Karazina Medicnij Fakul'tet

\section{Abadi Abay}

Haramaya University

Mekonen yimer

Haramaya university

\section{Sisay Menkir}

Haramaya University

\section{Melkamu Merid}

Haramaya University

\section{Research}

Keywords: Analytic Hierarchy Process; Malaria risk; Malaria trend; Weighted overlay

Posted Date: December 13th, 2019

DOl: https://doi.org/10.21203/rs.2.18671/v1

License: (c) (i) This work is licensed under a Creative Commons Attribution 4.0 International License. Read Full License 


\section{Abstract}

Background: Erer is one of the districts in Ethiopia where the first malaria transmission season occurs. Although the focus on malaria research has increasingly gained ground, little emphasis has been given to develop quantitative methods for assessing malaria hazard and risk in a temporal and spatial perspective.

Objective: To characterize and examine the temporal and spatial malaria trend. The research also aims at producing a predictive model of malaria hazard and risk in Erer district. Methods: In this study a cross sectional research design was used. It was carried out through the collection of both quantitative and qualitative data about the nature of malaria and household's response towards it. A multi-stage sampling method was used and 136 sample size was determined from the sampling frame of 6203 households. Simple descriptive analysis technique was used to determine the malaria trend of the district. Integration of Geographic information system and analytic hierarchy process was used to determine the weight of each factor pair wise comparison and weighted linear combination was used to aggregate and produce the hazard and malaria risk maps.

Results: Results have shown that $19.92 \%, 27.96 \%, 32.35 \%, 18.93 \%$ and $0.82 \%$ of the district was very high, high, moderate, low and very low malaria risk areas respectively. The malaria trend of the area was found to be variable across time with 2014 the peak year while the minimum case observed was in 2016.

Conclusion: It is possible to conclude that risk maps are important for estimating the scale of the risk, and enable detection of high risk areas, thus facilitating decision making and policy formulation for enhanced malaria control interventions. Key words: Analytic Hierarchy Process; Malaria risk; Malaria trend; Weighted overlay

\section{Introduction}

Globally, 300 - 500 million episodes of malaria illness occur each year, resulting in over one million deaths (WHO, 2015). More than $90 \%$ of the worldwide deaths from malaria occur in Sub-Saharan (Kleinschmid et al., 2001). It is also one of the most serious diseases to affect people in developing countries with tropical and subtropical climates. It is endemic in many countries and more than three billion of the world's population lives in malaria risk regions (Kirk et al., 2015) and (WHO, 2013).

It is estimated that $75 \%$ of the country is malarious with about $68 \%$ of the total population living in areas at risk of malaria (Worku, 2016; Sied, 2007). Malaria is a risk in the western and eastern lowlands and central midlands. It is further indicated that millions of people get sick and tens of thousands of people die due to malaria every year (Chikodzi, 2013). Spatially, there are areas where the risk of malaria is high and there are areas where the risk is low and according to sources (FMoH, 2009).

Erer is one of the districts in Ethiopia where the first malaria transmission season occurs (FDREMoH, 2004). It is a reason for high morbidity and mortality in the district. Malaria prevention and control system 
based on number of malaria cases report is time taking and lacks early response in times of epidemics (Woyessa, 2012). Therefore, integrative approaches that take environmental, socio economic and physical factors into account are needed to effectively reduce malaria burden (Sipe and Dale, 2003). Although the focus on malaria research has gained ground, little emphasis has been given to develop quantitative methods for assessing malaria hazard, risk and vulnerability in a temporal and spatial perspective.

National malaria programmes typically make operational decisions about where to implement vector control and surveillance activities based upon simple categorizations of annual parasite incidence. With technological advances, an enormous opportunity exists to better target specific malaria interventions to the places where they will have greatest impact by mapping and evaluating metrics related to a variety of risk components (Tuyishimire, 2013). The general objective of the study is therefore to characterize and spatially model malaria risk using analytic hierarchy process (AHP) and geographic information system (GIS). Specifically it is aimed at characterizing the temporal and spatial malaria trend of the district and map/model potentially malaria risk areas for preventative intervention.

\section{Methods And Materials}

\subsection{Location}

Erer is one of the districts in the Somali National regional state of Ethiopia. It is bordered on the south by Dire Dawa administration and the Oromia National regional state, on the southwest by Afdem district, on the northwest by the Afar National regional state and on the east by Shinile district (Figure 1).

Astronomically it is found between $10^{\circ} 15^{\prime} \mathrm{N}$ and $41^{\circ} 30^{\prime} \mathrm{E}$. The average elevation of the district is 824 meters above sea level. The track of the Addis Ababa Djibouti railway crosses the southern part of this district (CSA 2007).

\subsection{Economic activities}

Agro-pastoralism is the frequently practiced means of livelihood in the district. The rural households are being engaged in pastoralism and irrigation for the production of cash fruits such as lemon, orange, and Chat through irrigation. Orange is the most common cash fruit which is produced in the district. Irrigation is practiced along Erer, Tebe and Idora which are the three major rivers in the district. Petty trade, labor wages and off farm activities is also some of the means livelihoods in the district.

\subsection{Research design}

In this study a cross sectional research design was used. It was carried out through the collection of both quantitative and qualitative data about the nature of malaria and household's response towards it. It is also used to depict the nature or magnitude of malaria in the study areas.

\subsubsection{Sample size and sampling technique}


Sample size of these study kebeles was determined based on the simplified formula given by Jeff (2001).

$$
\mathrm{n}=\frac{X 2 N P(1-P)}{d 2(N-1)+X 2 P(1-P)} \quad=\frac{3.841 \times 6203 \times 0.1(1-0.1)}{(0.05) 2(6203-1)+3.841 \times 0.1(1-0.1)}=136 \mathrm{hhs}
$$

Where:

$\mathrm{n}=$ required sample size

$X^{2}=$ the table value of chi-square for 1 degree of freedom at the desired confidence level (3.841).

$\mathrm{N}=$ the population size

$\mathrm{P}=$ the population variability (assumed to be 0.10 since the population is homogeneous in terms of elevation, similar social class and similar economic activity (cash economy).

$\mathrm{d}^{2}=$ the degree of accuracy expressed as a proportion $(0.05)$.

On the other hand, in order to determine the number of sample (respondents) from Erer (S1), Dimtu (S2), Kentras (S3) and Bella (S4), the following formula was used.

$$
\mathrm{Sn}=\left(\mathrm{N}_{\mathrm{s}} / \mathrm{N}\right) * \mathrm{n}
$$

Where $\mathrm{Sn}$ is the sample size for kebele $\mathrm{S}, \mathrm{N}_{\mathrm{h}}$ is the population size for kebele $\mathrm{h}, \mathrm{N}$ is total population size, and $\mathrm{n}$ is total sample size.

Hence, $S 1=(N 1 / N) * n=(2150 / 6203) 136=47$ hhs

$$
\begin{aligned}
& S 2=(N 2 / N) * n=(1234 / 6203) 136=27 \text { hhs } \\
& S 3=(N 3 / N) * n=(1362 / 6203) 136=30 \text { hhs } \\
& S 4=(N 4 / N) * n=(1457 / 6203) 136=32 \text { hhs }
\end{aligned}
$$

According to Erer district Health office (2017), the study population was found to be homogenous in terms of geography, social class and economic activity (cash economy). Hence, a simple random sampling method was employed to select the sample respondents. In this study, a household data was used because different literatures boldly asserted that households are better to depict a more accurate and detailed information about problems. Besides, a non-probability sampling method (purposive) was also employed to select key informants.

Table 1: Summary of sample kebeles and households 
No Sample kebeles Household size Sample households Sampling technique

\begin{tabular}{clccl}
\hline 1. & Erer & 2150 & 47 & Simple random sampling \\
\hline 2. & Dimtu, & 1234 & 27 & Simple random sampling \\
\hline 3. & Kentras & 1362 & 30 & Simple random sampling \\
\hline 4. & Bella & 1457 & 32 & Simple random sampling \\
\hline & Total & 6203 & 136 & Simple random sampling
\end{tabular}

\subsection{Data sources and collection methods}

Both primary and secondary data sources were used in this study. Primary data was collected from the key informants and sample respondents. The primary data was supplemented by secondary data sources such as documents from Erer district health office, satellite imageries and NMA. A set of questions about the outbreak of malaria were developed in English and later translated to Somali language. The quality of the questions was tested in a pilot study and later distributed to the randomly selected 136 households. Check lists were also prepared to gather detailed information about the characteristics of malaria and its coping mechanisms as well as its severity from the key informants.

\subsection{Methods of data analysis}

Data obtained about the outbreak of malaria was analyzed using descriptive methods of data analysis (Yimer, 2017). Time series analysis was also employed to analyze the trends of malaria cases and temperature conditions in the district. This was made with the help of SPSS SPSS (Statistical Package for the Social Sciences). The household survey data was descriptively analyzed to identify the malaria outbreak conditions and examine the copying mechanisms of the local community. To know the malaria trend of the area ten (10) years from 2014 to 2016 malaria cases report was obtained from Erer district health office and the trend was determined. Data was entered and analyzed by SPSS software package. The frequency distribution of both dependent and independent variables were worked out by using crosstab. Finally, the data was described and presented using figures.

Geographic information science based multi-criteria decision analysis was used to identify the malaria hazard and risk factors and assign weights (Malczewski, 2006). The analytic hierarchy process which is a matrix where each criterion is compared with the other criteria, relative to its importance, on a scale from 1 to 9 . Where 1 = equal preference between two factors and 9 shows a particular factor is extremely favored over the other (Hong et al., 2000) was used. Both Malaria Hazard and Malaria risk were computed using weighted linear combination using the formula $\mathrm{H}=\sum$ wixi and $\mathrm{R}=\sum$ wixi respectively, Where, $\mathrm{H}$ - is the composite hazard score, $\mathrm{R}$ - is the composite risk score, $\mathrm{xi}$-is factor scores, wi is weights assigned to each factor and $\sum$ - is sum of weighted factors. Malaria risk of the district was 
analyzed from the following general risk equation. Risk $=($ Elements at risk $) \star($ Malaria Hazard $) *$ (Accessibility index).

\section{Results And Discussions}

\subsection{Trends of malaria cases in Erer district}

As per the data which is obtained from Erer district Health bureau (2017), malaria cases are currently being declining with some irregularities relative to the past. This is partly due to the frequently undertaken preventive measures such as spraying buildings with anti-mosquito chemicals, environmental sanitation campaigns, such as removing grasses and filling of water ponds, distribution of mosquito nets and providing mobile health cares.

The same source further indicated that the peak malaria transmission and severe season in the district is from May to September. Hence, the higher malaria cases are usually observed during the lowest rainfall months. In the last ten years, the maximum malaria case was recorded during 2006 whereas the minimum case was observed during 2015 (Figure 2) .

As clearly illustrated in Figure 3, malaria knocked majority of the sample respondents across all surveyed study kebeles. About $78 \%, 70.1 \%, 80.4 \%$ and $71 \%$ of the sample respondents of Kentras, Erer, Dimtu and Bella kebeles respectively reported that their families were affected by malaria and the remaining proportion of the surveyed households indicated that they were not affected by malaria. The major reason for this was found to be the proper usage of the mosquito nets and some of the actions by the government to prevent the outbreak of the incident. It is also found that almost all of the surveyed respondents reflected that malaria is the major problem and the most prevalent disease in the district. According to the district health experts (2017), mobile health cares are also other immediate but important strategies to overcome the outbreak of malaria. It is also further elaborated that early treatments such as soaking or dipping of mosquito net in a liquid to kill the mosquitoes, treating standing water with larvicides, avoiding standing water, cutting long grasses and mass awareness creation activities are found to be the most important measures in the district. However, some households are found to be practicing nothing and not taking any measure for the reason that they are never infected by the disease.

\subsection{Malaria risk factor maps}

\subsubsection{Malaria Hazard Factor}

The malaria hazard was computed by overlaying the following five factors of proximity to water body, elevation, slope, temperature and temperature wetness index in weighted overlay module of ArcGIS 10.4 (Table 2). 
Table 2. Pair wise comparison of hazard factors using AHP (obtained from IDRISI software)

\begin{tabular}{lllllll}
\hline Hazard Factors & Elevation & $\begin{array}{l}\text { Proximity to } \\
\text { water body }\end{array}$ & TWI & Temperature & $\begin{array}{l}\text { Slope } \\
\text { Eigen } \\
\text { vector } \\
\text { weights }\end{array}$ \\
\hline $\begin{array}{l}\text { Elevation } \\
\begin{array}{l}\text { Proximity to water } \\
\text { body }\end{array}\end{array}$ & 1 & 1 & & & & \\
TWI & $1 / 3$ & $1 / 2$ & 2 & 3 & 5 & 0.32 \\
Temperature & $1 / 4$ & $1 / 3$ & 1 & 2 & 4 & 0.2 \\
\hline Slope & $1 / 6$ & $1 / 5$ & $1 / 2$ & 1 & 3 & 0.16 \\
\hline
\end{tabular}

Table 3. Weight Determination (Saaty, 2008)

\begin{tabular}{|c|c|c|c|c|c|}
\hline Criteria & $\begin{array}{l}\text { Measurement } \\
\text { (Unit) }\end{array}$ & $\begin{array}{l}3 \\
\text { High } \\
\end{array}$ & $\begin{array}{l}\text { zard Level } \\
2 \\
\text { Moderate }\end{array}$ & $\begin{array}{l}1 \\
\text { Low }\end{array}$ & $\begin{array}{l}\text { Weight } \\
(\%)\end{array}$ \\
\hline Elevation & & 343-651 m & $\begin{array}{l}651-996 \\
\mathrm{~m}\end{array}$ & $\begin{array}{l}996- \\
2050 \mathrm{~m}\end{array}$ & 0.2 \\
\hline Slope & $\%$ & $<13 \%$ & $13-26 \%$ & $26-69 \%$ & 0.06 \\
\hline Proximity to water bodies & $\mathrm{km}$ & $<1.5 \mathrm{~km}$ & $1.5-5 \mathrm{~km}$ & $>5 \mathrm{~km}$ & 0.31 \\
\hline Temperature & $\mathrm{C}^{0}$ & 283- 268 & $268-240$ & $240-213$ & 0.15 \\
\hline $\begin{array}{l}\text { Temperature wetness } \\
\text { index }\end{array}$ & Unit less & $213-501$ & $501-603$ & $653-923$ & 0.24 \\
\hline
\end{tabular}

The hazard factor was obtained by simple additive weighting method using the formula. $\mathrm{H}=\sum$ wixi. Where, $\mathrm{Hi}=$ Hazard, wi refers to weight and $\mathrm{xi}$ refers to the variables used (Hailu, 2016). Hence it gives the following. $\mathrm{Hi}=\sum$ (Elevation*0.2 + proximity to water bodies * $0.31+\mathrm{TWl} * 0.24+$ Temperature $0.15+$ Slope * 0.04 ) which gives the following values (Table 3 ).

Table.4. Malaria Hazard of Erer district

\begin{tabular}{lllll}
\hline Cell Count & Ranking & Area $\left(\mathrm{km}^{2}\right)$ & Percent Area (\%) & Hazard \\
\hline 532,395 & 1 & 4791.5 & 34.91 & Very Low \\
324037 & 2 & 2916.3 & 21.25 & Low \\
\hline 128125 & 3 & 1153.18 & 8.4 & Moderate \\
\hline 197578 & 4 & 1778.49 & 12.95 & High \\
\hline 342705 & 5 & 3084.95 & 22.47 & Very High \\
\hline
\end{tabular}


Table 4 shows the extent of malaria hazard in the district. $22.47 \%$ or $3084.95 \mathrm{~km}^{2}$ of the area under investigation was very hazardous to malaria where as $12.95 \%$ or $1778.49 \mathrm{~km}^{2}$ of it was found to be under high malaria hazard. While $8.4 \%$ or $1153.18 \mathrm{~km}^{2}$ of the area was with moderate hazard $21.25 \%$ or 2916.3 $\mathrm{km}^{2}$ fall under low influence to malaria hazard. The remaining $34.91 \%$ or $4791.5 \mathrm{~km}^{2}$ area of the district was with very low category. Both the table and the hazard figure resemble the responses given from the questionnaires and interviews.

As can be noted from Figure 4, above spatially the malaria hazard of the district is classified in to very high, high, moderate, low and very low. As can be observed from the legend of the map the very blue colour represents very high hazard to malaria. Low laying areas with higher temperature were highly hazardous. The green color is showing areas with lesser hazards to malaria. In addition kebelles which were in close proximity to water bodies such as streams, irrigation canals and areas where there was sporadic rainfall are identified as very high and high hazard areas.

\subsubsection{Elements at risk factor}

Land use land cover types which are used to identify elements at risk were considered as important risk factors in malaria research. Maximum likelihood supervised classification technique was applied to classify the image in ERDAS IMAGINE 2014. Accordingly five land use/ cover classes namely, water bodies, forests, settlement/farmland, bush land and bare/open land were identified. The element at risk layer was then classified on the basis of malaria risk. Literatures revealed that the most important element at risk is the settlement or the farmland and were given high score (Lemessa, 2011). The table also shows next to settlement water bodies and forests can be a source of the vector.

Table.5. Elements at risk of Erer district

\begin{tabular}{l|l|l|l|l}
\hline Land cover Classes & Value & Area $\left(\mathrm{km}^{2}\right)$ & Percent_area (\%) & Risk \\
\hline Settlement/Farm land & 5 & 1,687 & 11.49 & Very High \\
Water body & 4 & 552 & 3.76 & High \\
Forest & 3 & 525 & 3.57 & Moderate \\
Bush Land & 2 & 5,887 & 41.06 & Low \\
Bare/open land & 1 & 6,028 & 40.09 & Very Low \\
\hline
\end{tabular}

Water body and forest were considered as most suitable for mosquito breeding based on literatures and malaria control experts. They were labeled as very high, forest as high, settlement as moderate farmland and settlement as moderate, bare and shrub lands as low. As a result 5, 4, 3, 2 and 1 were the new values given respectively. The above Table 5 also illustrates $11.49 \%$ of the area was under very high risk to malaria where as $40.09 \%$ was at very low risk. 
In Figure 5 above blue colors are representing water bodies such as streams, irrigation canals water pools etc. while forests are being colored by burnt umber. The dark and gray shades are showing settlements and bare lands respectively. The last macaw green is representing scattered bush land of the area.

\subsubsection{Accessibility index factor}

Vulnerability (Accessibility index) was generated from the district health centers point data. Areas found within $3 \mathrm{~km}$ radius from health centers are assumed to be at lesser malaria risk than areas found outside this distance (WHO, 2013). Hence, classes of distances $<3 \mathrm{~km}, 3-4 \mathrm{~km}, 4-5 \mathrm{~km}, 5-6 \mathrm{~km}$ and $>6 \mathrm{~km}$ were considered to buffer vulnerability index (Zewge, 2016).

Table 6. Accessibility index of Erer district

\begin{tabular}{lllll}
\hline Health facility distance & Ranking & Area $\left(\mathrm{km}^{2}\right)$ & Percent area (\%) & Vulnerability \\
\hline$<5 \mathrm{~km}$ & 1 & 1855 & 14.52 & Very Low \\
$6-15 \mathrm{~km}$ & 2 & 4643 & 36.34 & Low \\
\hline $16-25 \mathrm{~km}$ & 3 & 4490 & 35.15 & Moderate \\
\hline $26-36 \mathrm{~km}$ & 4 & 1692 & 13.25 & High \\
\hline$>36 \mathrm{~km}$ & 5 & 92 & 0.72 & Very High \\
\hline
\end{tabular}

As can be noted from Table 6 above the classes were given ranks of 1, 2, 3, 4 and 5 and were designated as very low, low, moderate and high and very high malaria vulnerability levels respectively. $0.72 \%$ or 92 $\mathrm{km}^{2}$ of the area fall under very high vulnerability to malaria because these areas are with scarce health facilities. $13.25 \%$ or $1692 \mathrm{~km}^{2}$ of the district is also highly vulnerable. The other $35.15 \%$ or $4490 \mathrm{~km}^{2}$ and 36.34 or $4643 \mathrm{~km}^{2}$ of the area was designated to be moderate and low vulnerability respectively (Figure 6).

Therefore access to health centers and hospitals in the area would greatly affect the population vulnerability to malaria.

\subsection{Aggregating risk criterion weights}

The pair wise comparison method in the analytic hierarchy process module was used to give weight for each factors (Saaty, 2008). While assigning the weights for the factors in IDRISI software previous researches, malaria control experts and local condition of the area under investigation were consulted (Table 7).

Table 7: Risk factor weights and rating and expert's opinion (IDRISI) 


\begin{tabular}{|c|c|c|c|c|c|}
\hline Factors & Value & Ranking & Weight & Area $\left(\mathrm{km}^{2}\right)$ & Risk \\
\hline \multirow[t]{5}{*}{ Hazard } & $100-160$ & 1 & \multirow[t]{5}{*}{0.5} & 8791 & Very Low \\
\hline & 160-195 & 2 & & 3916 & Low \\
\hline & $195-230$ & 3 & & 5153 & Moderate \\
\hline & $230-270$ & 4 & & 2778 & High \\
\hline & $270-300$ & 5 & & 2084 & Very High \\
\hline \multirow[t]{5}{*}{ Accessibility } & $<5 \mathrm{~km}$ & 1 & \multirow[t]{5}{*}{0.25} & 1855 & Very Low \\
\hline & $6-15 \mathrm{~km}$ & 2 & & 4643 & Low \\
\hline & $16-25 \mathrm{~km}$ & 3 & & 4490 & Moderate \\
\hline & $26-36 \mathrm{~km}$ & 4 & & 1692 & High \\
\hline & $>36 \mathrm{~km}$ & 5 & & 92 & Very High \\
\hline \multirow[t]{5}{*}{ Elements at risk } & Settlement & 5 & \multirow[t]{5}{*}{0.25} & 552 & Very High \\
\hline & Water bodies & 4 & & 525 & High \\
\hline & Forest & 3 & & 1,687 & Moderate \\
\hline & Bush land & 2 & & 5,887 & Low \\
\hline & Bare/open land & 1 & & 6,028 & Very Low \\
\hline
\end{tabular}

\subsection{Malaria risk mapping}

The development of malaria risk map of the study area was done on the basis of risk computation model (Shook, 1997). Risk = Element at risk * Hazard * vulnerability. The computed Eigen vector was used as a coefficient for the respective factor maps to be combined in weighted Overlay in the ArcGIS. Computing the overall risk as $\mathrm{R}=\mathrm{Hazard}{ }^{\star} 0.5 *$ Elements at risk*0.25*Vulnerability ${ }^{\star} 0.25$ would give the malaria risk $\mathrm{map} /$ model. The following tabular and map values are the final risk results produced from this calculation.

Table 8: Malaria risk of scales of Erer district

\begin{tabular}{lllll}
\hline Cell Counts & Values & Area $(\mathrm{km} 2)$ & Percent area & Risk \\
\hline 12223 & 1 & 109.50 & 0.82 & Very Low \\
278253 & 2 & 2504.00 & 18.93 & Low \\
\hline 475387 & 3 & 4278.40 & 32.35 & Moderate \\
\hline 410935 & 4 & 3698.40 & 27.96 & High \\
\hline 292700 & 5 & 2634.30 & 19.92 & Very High \\
\hline
\end{tabular}

The final out put raster layer generated by multiplying the risk components is the raster risk layer. It was reclassified according to the risk level in to five sub groups as very high, high, moderate, low and very low risk areas as given in Table 8, and figure 7, above. $19.92 \%$ or $2634.30 \mathrm{~km}^{2}$ of area was found to be under very high risk to malaria and this was also confirmed by the socio economic data collection tools. Areas which are found to be at very and high risk in the final malaria risk model were similar to the reports compiled from the questionnaires, interviews and district officials. The dark colored areas in the following map are showing areas of very high and high malaria risk zones. 


\subsection{Discussion}

In this regard a study conducted in New Juaben Ghana by (Kumi-Boateng et al., 2017), shows similar findings. Kebeles which are found along the major rivers in the district are the highly vulnerable areas to malaria. The field observation and distributed questionnaires confirm the impact of irrigation canals and intermittent streams and rivers especially around the town of Erer is enormous source of malaria breeding. The result of the study also shows areas which are located at lower elevations with high temperature and low rainfall were highly hazardous. Empirically above $50 \%$ of the area is highly malaria hazardous.

The result of the study has also confirmed that in areas where there is high concentration of health stations and clinics the vulnerability of the population to malaria risk seems less because with health service access there is the probability of being treated there. A similar study conducted in Boricha district Ethiopia has confirmed that there is less vulnerability of people with access to health service. In addition there is high tendency of malaria risk in areas of high population density (Senbeta, 2016). The elements at risk variable derived from the land use land cover have shown that different elements exposed to malaria incidence one of them being population. In general, as shown in figure large part of the district is in risk of malaria. Most of the kebeles in the study area are subject to moderate, high and very high risk of malaria.

\section{Conclusion}

In the study the trend of the malaria infection of the district was determined for the last ten years. It was found that there is alternate or dynamic trend with 2013 E.C being the peak year while the minimum case observed was during 2016 E.C. Further the distributed questionnaires and key informant interviews indicated that spraying buildings with anti-mosquito chemicals, environmental sanitation campaigns, such as removing grasses and filling of water ponds, distribution of mosquito nets and providing mobile health services were some of the malaria copying mechanisms employed in the district.

It is also found that Plasmodium Falciparum is the dominant malaria type which accounts $99 \%$ of the malaria type in the area. The results of the findings have shown that large part of the district was found in hazard and risk area to malaria. The risk areas identified in the hazard and risk models were compatible to the findings from the questionnaires and interviews.

\section{Declarations}

\section{ACKNOWLEDGMENT}

The authors extend their gratitude to the Haramaya University research office for the financial support for conducting this research. In addition, our gratitude goes to Erer health office workers and staff members for the overall support they gave us in our secondary data collection and the fieldworks. 


\section{AUTHORS' CONTRIBUTION}

All authors have made their shares to this manuscript. The mapping part was holistically performed by principal investigator. The socio economic data gathering and analysis was made by the co-investigators. Other members have contributed in collecting physical, socio economic and malaria case reports form the study area.

\section{FUNDING}

This study was supported by Haramaya university yealy grunt.

\section{AVAILABILITY OF DATA AND MATERIALS}

The data and material in this file were available by contacting Mr. Maereg Teklay

<maeregteklay@gmail.com>

\section{ETHICS APPROVAL AND CONSENT TO PARTICIPATE}

Not applicable

\section{CONSENT FOR PUBLICATION}

All authors have read and agree to publish this article.

\section{CONFLICT OF INTEREST}

The authors declare that there is no conflict of interest

\section{References}

Abbas, M., Ahmad J., Khalil N., Zainab K., Norhayati Z. and Alireza V .2015. Multiple criteria decisionmaking techniques and their applications - a review of the literature from 2000 to 2014, Economic Research-Ekonomska Istraživanja, 28:1, 516-571, DOI: 10.1080/1331677X.2015.1075139.

Abiodun, M., Adeola, J., Jane M., Olwoch, H., Ahmed M, Philemon Tsela, M., Omolola A, Francis W., Paul M., and Ausi S., (2015). Application of geographical information system and remote sensing in malaria research and control in South Africa: a review, Southern African Journal of Infectious Diseases, DOI: 10.1080/23120053.2015.1106765.

Ahmed, A. .2014. GIS and remote sensing for malaria risk mapping, Ethiopia. he International Archives of the Photogrammetry, Remote Sensing and Spatial Information Sciences, Volume XL-8, 2014 ISPRS Technical Commission VIII Symposium, 09 - 12 December 2014, Hyderabad, India. 
Chikodzi, D. 2013. Spatial Modeling of Malaria Risk Zones Using Environmental, Anthropogenic Variables and Geographical Information Systems Techniques. Journal of Geosciences and Geomatics, 2013, Vol. 1, No. 1,8-14.

CSA (Central Statistical Agency) of Ethiopia .2012. Population and Housing Census Report. Addis Ababa, Ethiopia.

FAO (Food and Agriculture Organization). 2006. Guidelines for soil description. $4^{\text {th }}$ edition. Rome. Italy. FAO/WFP. Rome. (http://www.fao.org./GIEWS) (Accessed on June 21, 2016).

FDREMoE (Federal Democratic Republic of Ethiopia Ministry of health) .2014. National Malaria program monitoring and evaluation plan 2014-2020. Addis Ababa, Ethiopia.

FMoH (Federal Ministry of health). 2009. National Strategic Plan for Malaria Prevention, Control and Elimination in Ethiopia 2010 - 2015. Federal Ministry of Health, Addis Ababa, Ethiopia.

Francis, O.M., Felix N.M. and Markkipkurwa B. 2016. Malaria Risk and Vulnerability Assessment GIS Approach. Case Study of Busia County, Kenya. OSR Journal of Environmental Science, Toxicology and Food Technology (IOSR-JESTFT) e-ISSN: 2319-2402 - ISSN: 2319-2399.Volume 10, Issue 4 Ver. I Apr. 2016, PP 104-112.

Hailu, K. 2016. Malaria risk assessment using geographic Information system (GIS): a case of Adama district, Ethiopia. ESRI, EAST AFRICA Education GIS CON., SEP, 2016

Hassaan, M.A., Abdrabo, M.A. and Masabarakiza, P. 2017. GIS-Based Model for Mapping Malaria Risk under Climate Change Case Study: Burundi. Journal of Geoscience and Environment .Protection, 5,102117https://doi.org/10.4236/gep.2017

Hong, J. and Eastman R. .2000. Application of fuzzy measures in multi-criteria evaluation in GIS, International Journal of Geographical Information Science, 14:2, 173-184, DOI:

10.1080/136588100240903.

Jeffrey, F. 2001. Sample size determination for interval estimation of multinomial probabilities. The American Statistician. Taylor \& Francis Group.

Kebede, Y., Bewket, E., and Belete, W., 2017. Malaria Hazard and Risk Mapping Using GIS Based Spatial Multi criteria Evaluation Technique (SMCET) in Tekeze Basin Development Corridor, Amhara Region, Ethiopia. Journal of Environment and Earth Science www.iiste.org ISSN 2224-3216 (Paper) ISSN 2225-0948 (Online) Vol.7, No.5, 2017.

Kirk, E., Haq M., Alam M., and Haque M., .2015. Geospatial Technology: A Tool to Aid in the Elimination of Malaria in Bangladesh. ISPRS International Journal of Geo-Information ISSN 2220-9964 www.mdpi.com/journal/ijgi/. 
Kleinschmid, I., Judy O., Olivier B., Nick V., Nafomon S., Nathan K., Pieter W., Mahaman M., and Thomas T. .2001. An empirical malaria distribution map for West Africa. Tropical Medicine and International Health. Volume 6 no 10 pp 78-86.

Kumi-Boateng, B., Bonsu, K., and Mireku, N. 2017. Mapping Malaria Risk in the New Juaben Municipality of Ghana using GIS and Remote Sensing Techniques. Ghana Journal of Technology, Vol. 2, No.1, pp. 27 - 37.

Lemessa, A.2011. GIS and remote sensing based malaria risk mapping in Fentale Woreda, East Shoa zone, Ethiopia. A thesis submitted to the school of graduate studies of Addis Ababa University, in partial fulfillment of the requirements for the degree of Master of Science in remote sensing and geographic Information system.

Malczewski, J .2006. GIS - based Multi-criteria Decision Analysis: A Survey of the Literature. International Journal of Geographical Information Science. Vol. 20, No. 7. P 703-726.

Moss. J., Harry. H., Tamaki. K., Timothy. S., Aniset. K., Julie. C., Sungano. M., Philip. T, and Gregory G. .2011. Use of remote sensing to identify spatial risk factors for malaria in a region of declining transmission: a cross-sectional and longitudinal community survey. Malaria journal. 10:163.

Paaijmans, P. .2014. Downscaling reveals diverse effects of anthropogenic climate warming on the potential for local environments to support malaria transmission.

Saaty, T. .2008. Decision making with the analytic hierarchy process. Int. J. Services Sciences. Vol. 1.

Seid, A. .2007. GIS and remote sensing integrated malaria risk mapping in dembia woreda, northern Ethiopia, a thesis submitted to the school of graduate studies in partial fulfillment of the requirements for the degree of Master of Science in GIS and remote sensing in earth science.

Senbeta, A., Kanko T. and Ferede T. 2016. Malaria Distribution in Kucha District of Gamo Gofa Zone, Ethiopia: A Time Series Approach. American Journal of theoretical and applied Statistics. http://www.sciencepublishinggroup.com/j/ajtas doi: 10.11648/j.ajtas.20160502.15 ISSN: 2326-8999 (Print); ISSN: 2326-9006.

Sipe, G., and Dale, P., (2003). Challenges in using geographic information systems (GIS) to understand and control malaria in Indonesia. Open access. Review. Malaria Journal.

Shook, G. .1997. An assessment of disaster risk and its management in Thailand. Disasters, 21(1), 7788.

Tiruneh, A. 2010. GIS and Remote Sensing Based Assessment of Malaria Risk Mapping for Boricha district, Ethiopia. A thesis submitted to the school of graduate studies of Addis Ababa University in partial fulfillment of the requirements for the degree of Master of Science in remote sensing and GIS. Addis Ababa, Ethiopia. 
Tuyishimire, J. 2013. Spatial modeling of malaria risk factors in Ruhuha sector Rwanda. A thesis submitted to the faculty of Geo-information Science and earth observation of the University of Twente in partial fulfillment of the requirements for the degree of Master of Science in Geo-information Science and earth observation. Enschede, the Netherlands.

WHO (World Health Organization). 2010. Guideline for the treatment of malaria, $2^{\text {nd }}$ edition. Geneva: Switzerland. Pp. 12-13.

UNICEF (United Nations International Children's Emergency Fund). 2008. Achieving the malaria MDG target reversing the incidence of malaria 2000-2015.Geneva, Switzerland. (http:unicef.org/Ethiopia) (Accessed on July 11 2016).

WHO (World Health Organization). 2013. Global malaria program, world malaria report. France, pp.66-70.

WHO (World Health Organization). 2015. World Malaria Report. Geneva, Switzerland, pp.120-121.

Worku, T. 2016. Geographic Information System and Remote Sensing Based Malaria Risk Mapping: A Case of shone town administration, Southern Nations Nationalities and Peoples' Regional State. A thesis submitted to the school of graduate studies of Addis Ababa University in partial fulfillment of the requirements for the degree of master of art in GIS, remote sensing and digital cartography. Addis Ababa, Ethiopia.

Yimer, M., Hailu T., Mulu W., Abera B., and Ayalew W. 2017. A 5 year trend analysis of malaria prevalence with in the catchment areas of Felegehiwot referral Hospital, Bahir Dar city, northwest-Ethiopia: a retrospective study. BMC Research Notes. DOI 10.1186/s13104-017-2560-6.

Zewge, M., .2016. Malaria risk assessment using GIS and remote sensing: a case of kewet woreda, north Shewa zone, Amhara region. A thesis submitted to the school of graduate studies of Addis Ababa University in partial fulfillment of the requirements for the degree of master of art in GIS, remote sensing and digital cartography. Addis Ababa, Ethiopia.

\section{Figures}




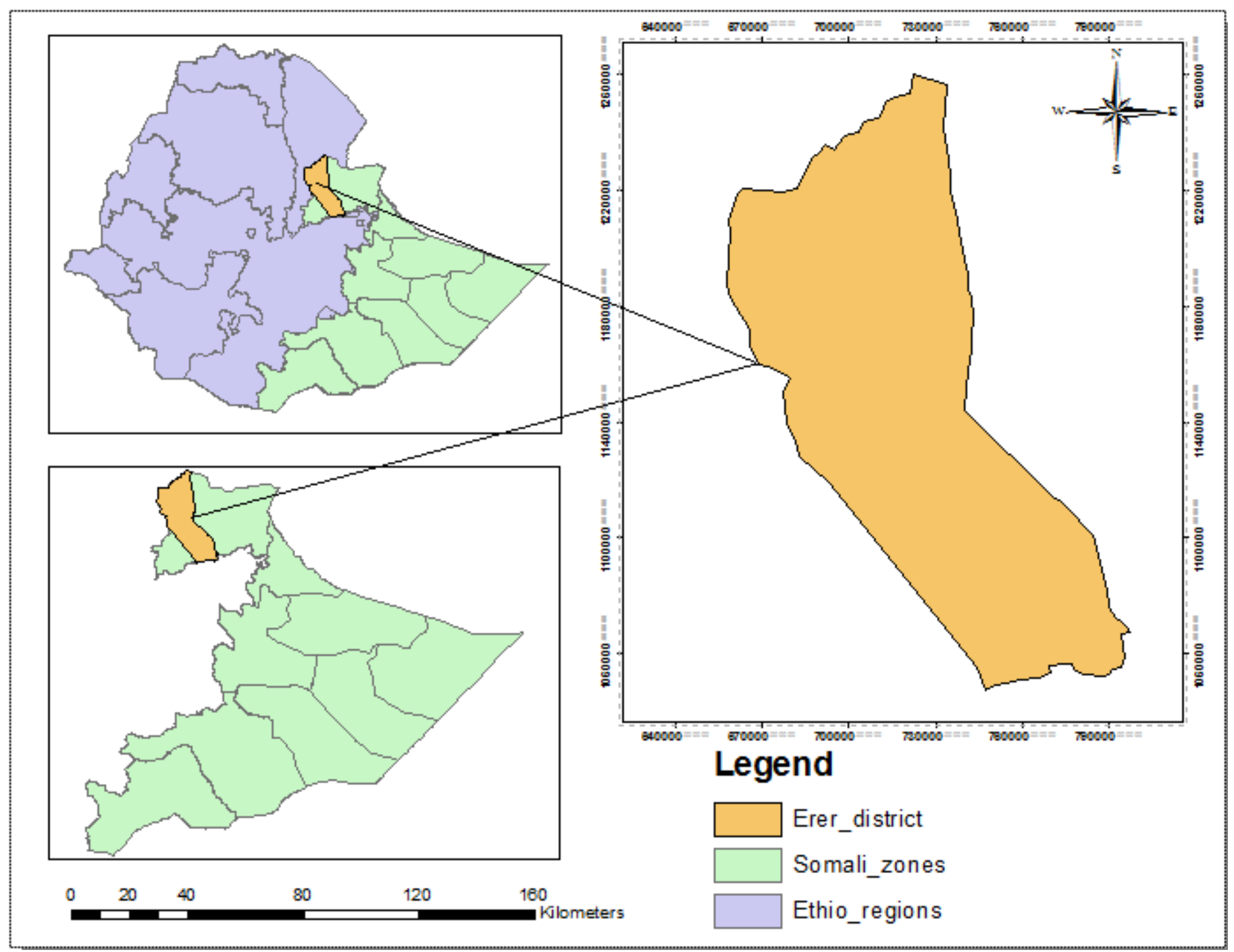

Figure 1

Location map of the study area Source: CSA, 1997. 


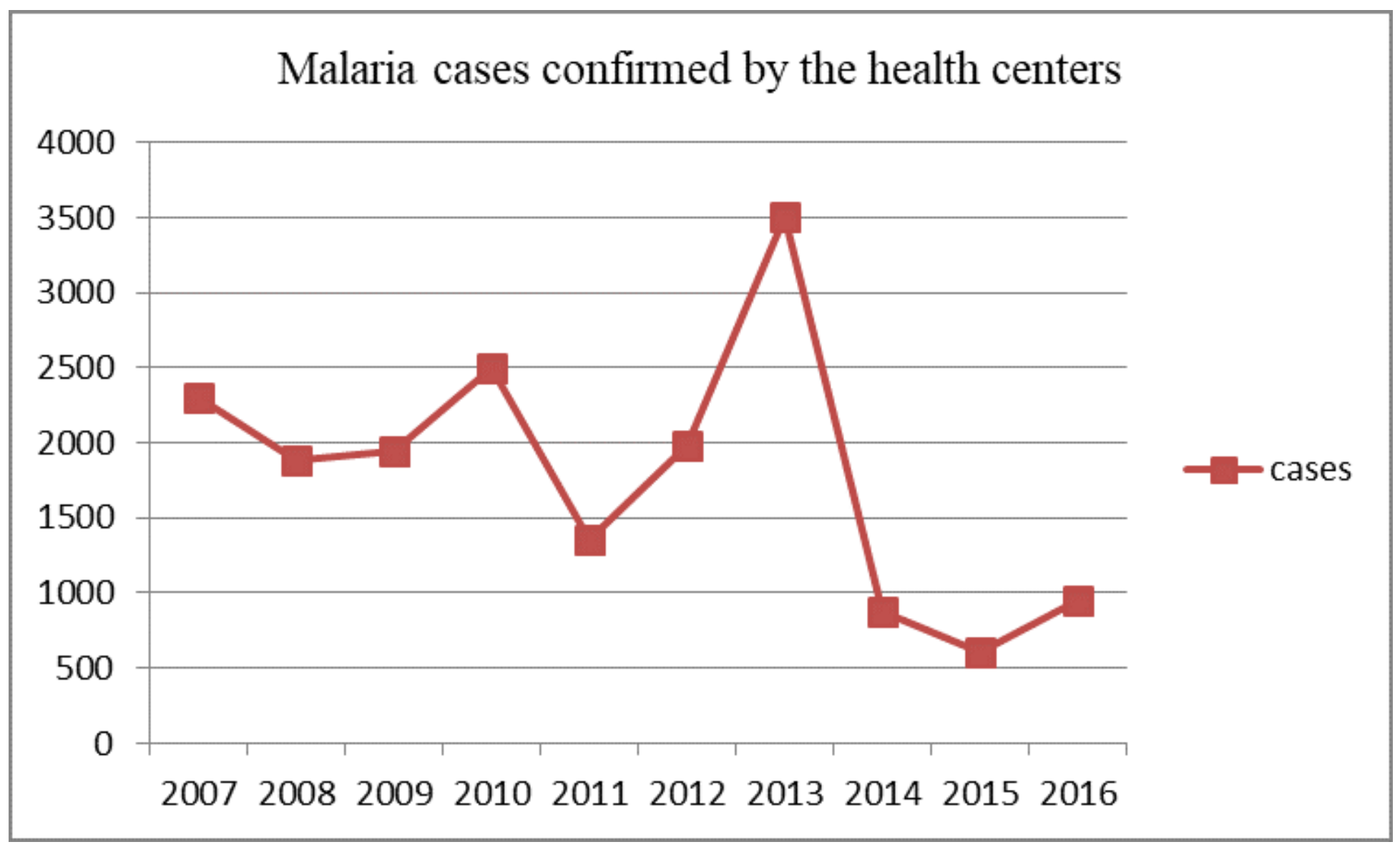

Figure 4

Trends of malaria disease in Erer District Source: Erer District Health Bureau, 2017 


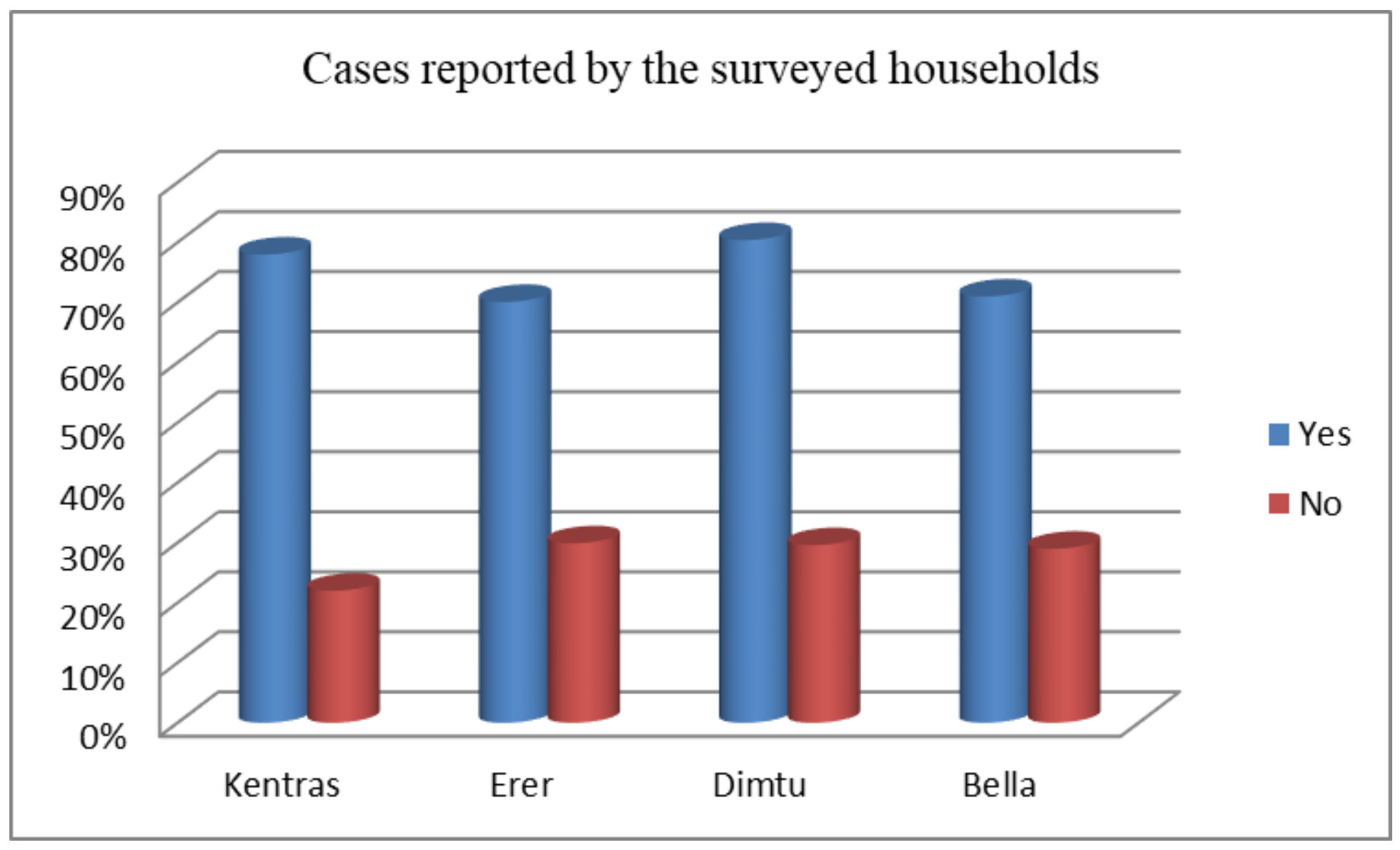

Figure 6

Malaria cases reported by the surveyed households Source: Own field survey (2017) 


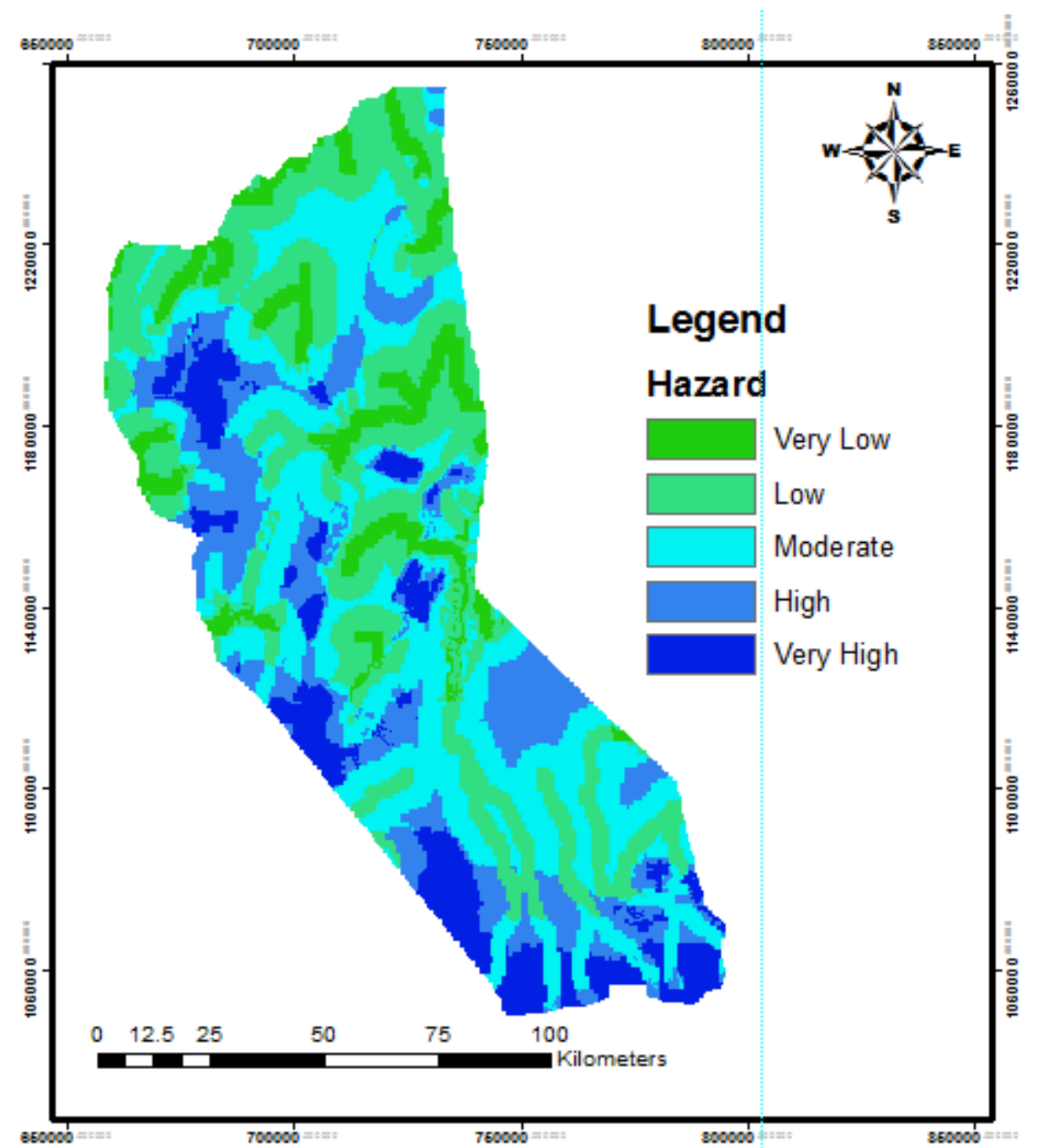

Figure 8

Malaria Hazard map of Erer district 


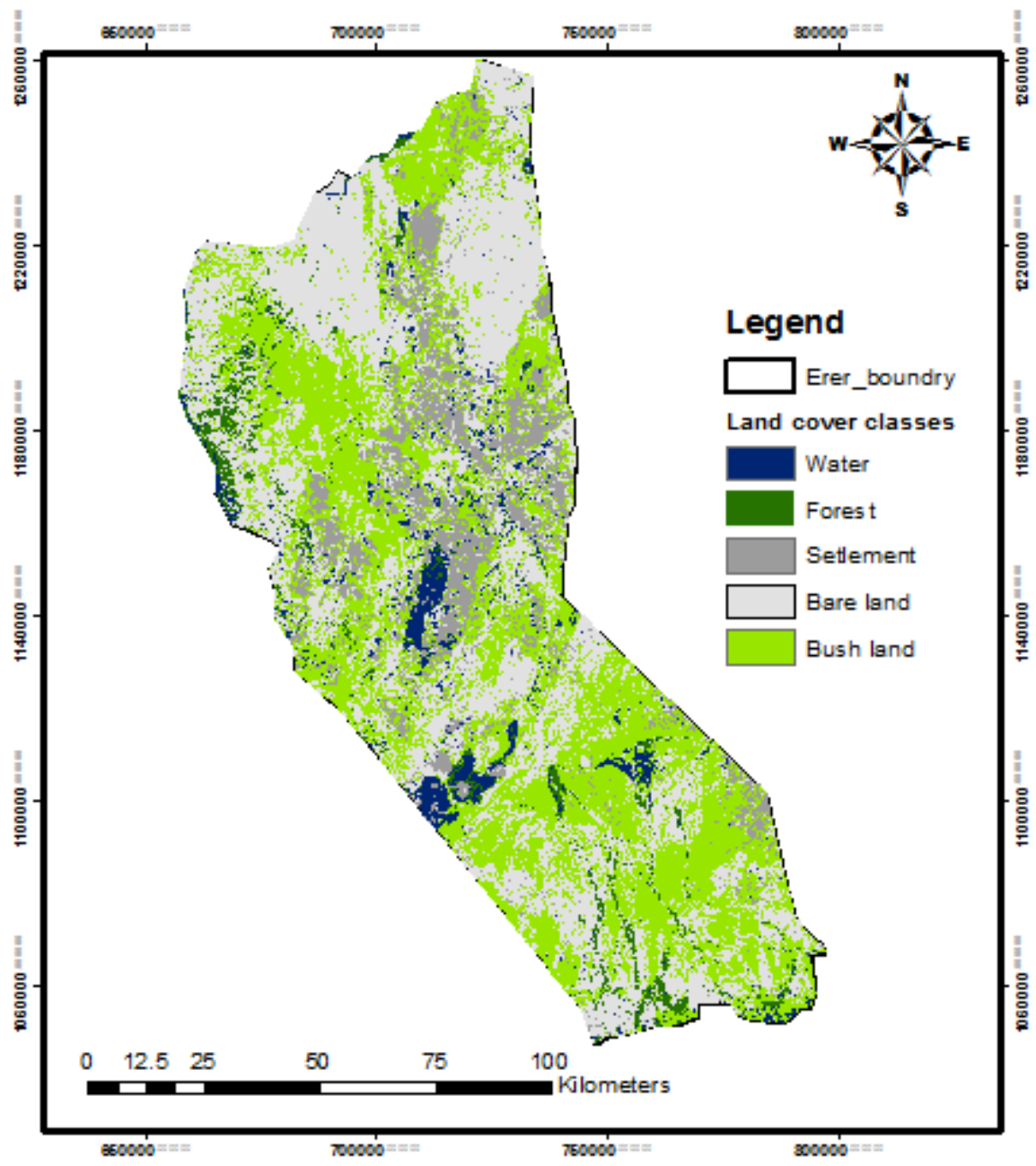

Figure 10

Elements at risk map of Erer district. 


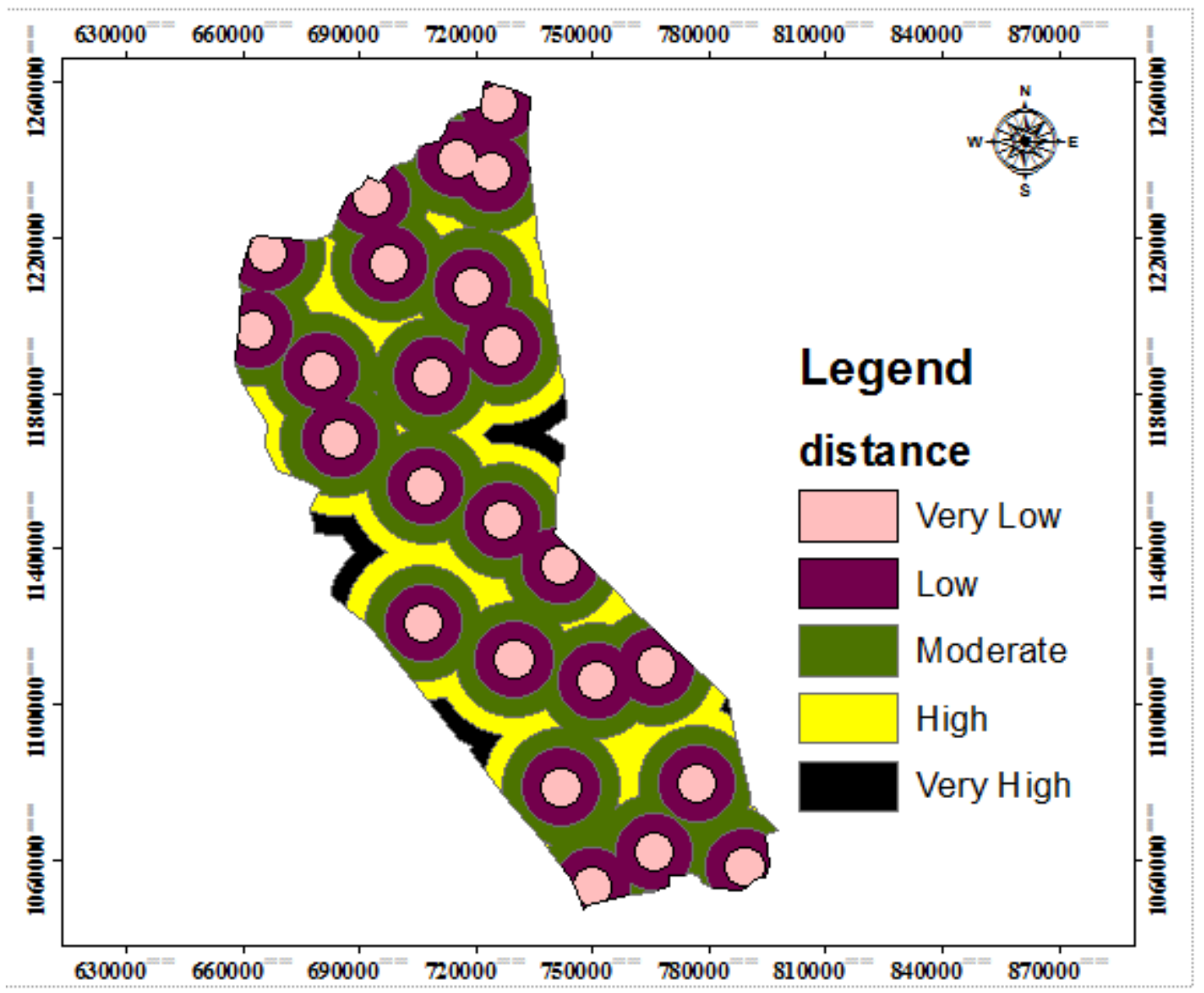

Figure 12

Vulnerability index map of Erer district

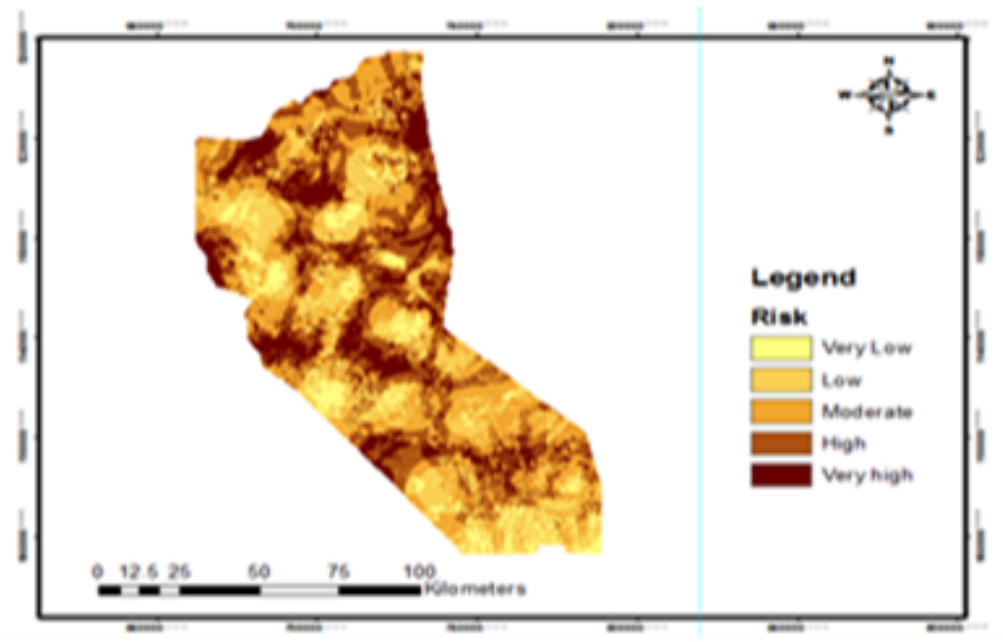

Figure 13

Malaria risk map of Erer district 